\title{
The Indian Tribal Art Market
}

\author{
Farzaneh Maleki Dizaji \\ Savitribai Phule Pune University Tehran, Iran \\ farzaneh.maleki.dizaji@gmail.com
}

\begin{abstract}
In the study of art market of Indian tribal, creativeeconomy, cultural economy effect on consumer behavior, governmentprotection, changes of cultural believes and religion by tribal for increasing market, art economic etc. has been considered. In Indian tribal art economics, creative imagination coming from their culture, believes, religions etc. So it becomes more sensitive and restricted. The Field work was conducted in Bhopal (IGRMS), Madhya Pradesh, India. Data collection was performed by qualitative informal depth interview and quantitative data by questionnaire. Tools and technique were including photography, observation; case study (Bhil and Rathwa communities) Research duration was fromMay2015 to March 2016. Consumers of Indian tribal art divided to four categories: foreigners, NRI, artist and very rare common people. The government protection of Tribal art is based on Article 342. The protection is governed by the Ministry of Culture and Ministry of Tribal affairs, Government of India. And also by organizations like IGRMS, TRIFED, TRTI, Lalit Kala Academy etc. Protection of arts in India is performed under section 22 of the copy right Act 1957, intellectual property right and also scheme of "Market Development of Tribal Products/ Produce. In conclusion art marketing doesn't have a particular formula for all type of art because they have different target audience.
\end{abstract}

Keywords: Art Market, Creative Economy, Cultural Economy, Indian Tribal Art, Indira Gandhi Rashtriya Manav Sangrahalaya (IGRMS)

\section{Introduction}

The art market can be defined as a field in which artists, sellers ,buyers and the art enthusiasts community ,interact with each other .It is a sphere where cultural imagination gets converted in to monetary terms .Art market is based on interactions and interrelations of supplier (artists) and demander ( customers of art) and middle men . In the economic pricing cultural values is very important. The art market involves different subjects as Psychology, anthropology, economic ,marketing and sociology .the art market created in order to commoditization of art through its sale ,purchase and use as an asset .Art market changed by the time, artists, dealers and audience. In order to have a market for art, art should have some value, that value can be a cultural, historical, symbolic etc.This paper consider more cultural value of the art in the Indian tribal communities. Art market economics should cover protection of arts by private and public sector, related policy, taxation, impact of art economics on the life of the artists. In the study of art market we face two types of economics, Macro Economic and Micro Economic .Macro Economic related the art economics included the art market studies, socio -economic problems related to artists, price levels etc. and Micro Economic included activities or changes that artists should do for sales increase etc. Here we should mentioned when one artwork done just for commercial purpose the nature of art work change to the commodity, so all rules should considerfor selling of one commodity. Three important indicators in economic as production, distribution and consumption should consider for the art work that done special for sell. Important points regarding the art economics are as follow:

- Pricing behavior that determine by the artist and some organization, government sectors or private sectors.

- Decisions of artists that related to their culture.

- Policy examination of government grants to the arts.

- Laws regarding the rights of the artists as Droit moral, copy right law and Droit de suite, artist should obtain fixed percentage of the resale profit.

This paper discussed about art market economics of Indian tribal.In starting better we summarized the characteristics of tribal economics of India. Because of economic problems as deficiency of capital, landlessness, displacement, deficiency of irrigation water, the agriculture in India depended to the monsoon so due to low rainfall the tribal face many economic problems so they unable sustain their economic. In this 
condition they shift from agriculture job to another job. Many tribal from primary sector agricultural turn into jobs related toart. However to resolve their economic problems they do some changes in theirart,in religious paintings elimination of sacred symbols in their paintings.Tribal economic faced twoimportant aspect of their culture, religious and economic that how to create proper relationship between these two aspects of culture with respect to their religions.

\section{Literature Review}

India is a country situated in South Asia .The history of India reaching back to 5 millennia, So India is one of the world's oldest country with diverse cultures. Indian culture exposed its tradition, arts, values, believes, religionsetc.The $60 \%$ of Indian people are belong the primary sector, agriculture but unfortunately agriculture in India is depended to the monsoon (rainy season). When the rain fall is less farmers are turning to other jobs as construction labors, industry, sale of hand craft and artworks etc.

India is second country after Africa in number of tribal .There is diversity in Indian tribalcommunities, but there are some commoncharacteristics in Indian tribal economics. These characteristics are as follow:

- Production without using modern technology

- Relation of economic and religious

- Production for consumption

- Barter system in tribal economic

- Community basis of economic activities (As Balutedar system)

- Economic backward

These problems in tribal economics cause shifting economic shifting economic refer to changes of economic resources during a period of time as shifting agriculture to selling art works. When the number of shifting in the economic increased it showing the instability in the economic system of one community. The Rah are Adivasi that found in the boundary of Gujrat and Madhya Pradesh. Agriculture is the main occupation of the Rathwas but many Rathwas engaged in industrial work, gardening, construction work or casual labor, selling Pithora paintings and work as artist in IGRMS etc. Pithora paintings are religious wall paintings that the main elements are horses, in their believes the horse is vehicle of god for coming to village and help them. Performance of Pithora painting in Rathwa house brings peace, prosperity and happiness. The Pithora paintings are more a ritual and performance to thank god or a wish for solving problems. In the traditional forms the artists used the natural colors that made by plants, but now a day artists use acrylic colors for attract more customer.

\section{Figuer 1 : (A)Traditional Pithora paintings,(B)Commercial Pithora paintings}

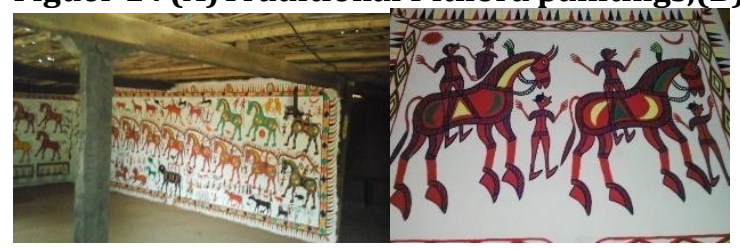

(A)

(B)

The traditional paintings presented on the walls of kitchen in house because for Rathwas kitchen is sacred place at house .Traditional paintings done by natural colors that made by plants. The Commercial Pithora paintings is part of the complete traditional Pithora paintings that done by acrylic colors .Acrylic colors are more brightness than natural colors, so this brightness attractmore customer .In believe of the Rathwas complete paintings are sacred. The Bhil are recognized as the oldest inhabitants of the southern Rajasthan, parts of Gujarat and Madhya Pradesh. The source of the income for Bhilsare agriculture, animal husbandry, selling of paintingsand working as an artist or laborers in IGRMS etc. The Bhils do different types of the paintings in different occasions as: Gohri painting, Tharvi painting, Pithora painting,Bhagoria painting, Gatle painting.Most of these paintings are religious paintings for different occasion and purposes.The roots of the Pithora paintings can find in the cave paintings, more than thousands of years old. Because of economic problems Bhils present these paintings for sell by some changes. 
Figuer 2: (A)Traditional Gatle paintings,(B)Commercial Gatle paintings done by Bhil communites

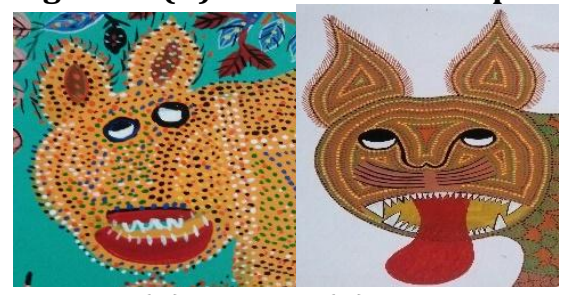

(A)

(B)

The traditional Gatle paintings done by the natural colors and commercial Gatle paintings done by Acrylic colors .The style of the Bhil paintings changed because of attract more customers for increasing marketing. In the area of art market economics we should mentioned to creative economy and cultural economy .Creative economy and cultural economy mentioned as an important and growing part of the global economy .Creative economy refer to one type of economy that main resources of economic are creative imagination to increase one ideas values. It is different with traditional resources in economics as labor, land and capital (John Howkins 2001).Compared to creative industries, which are restricted to specific sectors, the term is used to describe creativity throughout a whole economy. In art economics of Indian tribal creative imagination coming from their culture, believes, religionsetc. So for this matter art economics of Indian tribal become more sensitive and restricted.

Cultural economy refers to relation of culture and economic that effected on the output of economical product. In total analyzing about cultural economy represent that how ideas and individual behavior effect on the marketing of products. The nature and role of the culture in the societies according to the time change by acculturation, modernization, globalization etc.Based on these changes the demand and consumption also will be change .Demand for economical product in developed, developing and under developed countries are different .In the sphere of art most of the developed countries showing more interest to art of developing countries and under developed countries as Indian and African art.

\section{Methodology}

The Field work was conducted in Indira Gandhi Rashtriys Manac Sangrahalaya (IGRMS), an anthropology museum and some villages located in Bhopal, Madhya Pradesh, India. Data collection was performed by qualitative informal depth interview and quantitative data by questionnaire. Tools and technique were including photography, observation, case study (Bhil and Rathwa communites), Informants and key informants Secondary sources of data collection. Research duration was fromMay2015 toMarch 2016.

\section{Result and Discussion}

Tribal paintings are part of tribal culture production these paintings are belong their culture, believes, tradition and most important part belong to their religions. So some of these paintings are sacred for Indian tribal and we can observed the religious symbols in their paintings, before and after presenting the painting in Bhil and Rathwa communities ,they done pray (Pooja)and religious ceremonies. There are some restrictions for artists for providing these paintings for sell because art works are closely connected to religious and sacred thoughts that these thoughts transmitted from generation to generation. Culture is identity of each community and society. When we study about the economics related to tribal paintings same each commodity we should consider three important factors: 1-production 2-distrubition 3- consumption

- Production is done by the tribal and we considered about the procedures, elements, materials that they used, believes and changes that artist done for better selling of commercial paintings.

- Distribution of tribal paintings most happen by government organizations as museums, tribes India shop, government sites for online shopping etc. Part of the distribution of tribal paintings done by privet sector .Many private business are regarding tribal paintings in inside and outside of the India .This business become very profitable for foreigners, they buy these paintings very cheap in India from the tribal artists and they sell very expensive in other countries. 
- Consumption: The type of the consumer of tribal paintings can divided to different categories as:foreigners, a Non -Resident Indian (NRI), artists and very rare common people .The researcher searched for this question that, why the number of the common people as customers for tribes shop is less.

The result of questionnaire showing thecommon people don't have adequate knowledge about tribal paintings. Most of the people knowing just Warli paintings because the motifs of Warli paintings using in their daily commodities as cup, clothes, notebook etc. Creative economy in tribal economies refers to economic sourcesare paintings that they create. They sell paintings in different places special government organizations. So the changes in tribal paintings are because of increasing the rate of the sell. Changes in Tribal paintings occurred because of human needs. In the tribal paintings basic motifs remained same .Changes in some tribal paintings done in the size that become easier for buyers use in their places so the traditional paintingsthat was on the wall reduced. Changes in some tribal paintings are because of cultural contact, acculturation .therefore by cultural contact art from one culture transmitted to another culture. All tribal paintings in folk are a part of any ritual, marriage chowk illustrating story or mythology. The traditional Bhil paintings performance on the wall but commercial Bhil paintings presented on canvas and paper that some motifs also changed .By this way demander for Bhil paintings can have Bhil paintings in their houses .Old people follow their grandfather rules without consideration of commercial purpose but young artists consider more selling purpose .Hence for this reason they used very bright color for attract more customer .City artists are different with artists that live in the village .The young artist see the TV and they access to the internet, social media so media is one of the reason for acculturation in the tribal art .

The paintings are second job of many artists and when they return from the city to their village they do agriculture. The educated artist knew the mythology and use mythology in their paintings this matter make paintings more attractive but the illiterate artist can't explain the story. The Bhils believed that complete Pithora paintings (religious paintings in Rathwa and Bhil communities) on the walls are religious but for commercial purpose just they made $25 \%$ of this painting on the paper and canvas not complete paintings .By this way the different people can have this paintings on their wall by buying these Pithora paintings. Modern changing in Pithora paintings improved for selling purpose. The artists of Pithora paintings change some rules of paintings as changing the surface and materials used for painting.In this paper Pithora paintings in Bhil and Rathwa communities was a case study that describe how Indian tribal adjust their believes and religion symbols with market .Selling of paintings are one source of income so for survival they should adjust their believes with market otherwise they face many economic problems .Socio - economics problems of Indian tribal artists are as follow:

Loading of loan, Alcoholism between men and women artists (Tadi and Pum juice) ,They didn't developed because most of them are illiterate, Religious system in Hinduism, ancestors, god etc. performing different worship need too much money, No constitution binding in their religious.

Government protection for tribal art is based on protection of Scheduled tribes under Indian constitution Article 342 by Ministry of Tribal Affairs Government of India and Ministry of culture.The government organizations protects tribal artistsby:

- IGRMS: Indira Gandhi Rasht Riva Manav Sangrahalaya

- TRIFED: Tribal Cooperative Marketing Development Federation of India Limited

- TRTI: Tribal Research \& training institute

- Lalit Kala Academy: National Academy of Arts (promotes and propagates understanding of Indian art).

Ministry of Tribal Affairs of Government of IndiaIn 1987, the Tribal Cooperative Marketing Development Federation of India Limited (TRIFED) was set up with an aim to serve the interest of the tribal community and work for their socio-economic development by conducting its affairs in a professional, democratic and autonomous manner for undertaking marketing of tribal products. By the Scheme of "Market Development of Tribal Products/ Produce ", the tribes shop established by TRIFT for purpose of selling the tribal art. Tribes India shops have 39 branches in whole India.Different products could find in tribes India shop that most of them produced by the tribal. One of the products is tribal painting. The pricing of the tribal paintings is under the ministry of tribal affairs but sometimes there is negotiation with artists and ministry of tribal affairs about pricing.In year one or two time the Ministry of Tribal Affairs arrange workshops and seminar for the artist of 
all India.The purpose of these seminars are, training program, design development. Actually these workshops arefor modification of tribal paintings by these way artists can adjust themselves by recent market.

Ministry of tribal affairs prepared a draft of the National Tribal Policy. This policy provide the socio-economic and political empowerment of tribal .This empowerment done by protection of cultural and traditional rights ,protection by intellectual property rights regime ,protection of tradition heritage as art, crafts .dance and music .These protection come under the government of India, TRIEFD and ministry of tribal affairs and some private sectors. This paper research was based the production and market of tribe's paintings of Central India. However the tribal policy in all over India is same. Protection of arts in India under section 22 of the copy right Act 1957 and Intellectual property right. These protections are for tribal rights ofavoiding commercial exploitation of tribal. The culture of each society effected on the consumer behavior members of the societies. When the source of income be paintings we can observed the direct relation of art and economic. Most important factors in marketing are trust; targeted audience and budget .Trustis include the knowing and belief of the people about products that introducing productsdone by different ways that social media is a powerful tool. Targeted audience refer for which type of group of people are demander for a particular product. Budget refers to amount of money that provided for production of one product. Each producer want increase sales, improve the profit margins of a company. Budget strategically planned for better profit. The physical budget that tribal spend for providing their arts is not too much because the capital source is more imagination,creatively and innovation .

\section{Conclusion}

In the study of Indian tribal art market mentioned to Creative economy and Cultural economy that effected on consumer behavior, governmentprotection, changes of cultural believes and sacred by tribal for increasing market, art economic etc. In Indian tribal art economics, creative imagination coming from their culture, believes, religionsetc. So for this matter art economics of Indian tribal become more sensitive and restricted. The folk and tribal art in India are not just aesthetic objects but in fact have an important significance in the people's lives and it tied to their beliefs and rituals. Tribal artists generally lack access to physical markets to sell their artworks. In general, tribal artists have only rudimentary knowledge about business .So some traders use of this condition buy the tribal paintings and sell these paintings more than triple of actual price inside or outside of India. Although business on Indian tribal paintings became job of many foreigners, they buy tribal paintings in India very cheap and sell them in their countries with higher rate.Comparison between government sector and privet sector showing government sectors consider more benefit of tribal and private sector consider more benefit of themselves. In general tribal art has been changed in favor of modernization. This modernization brings prosperity in the tribal community. The tribal adjust their believes with modernization. They eliminated the sacred elements in commercial paintings.

Modern tribal art or commercial paintings bring beautiful artwork to the world the traditional paintings from the wall came to the paper and canvas. Reasons for changes in tribal paintings are: Acculturation, Rapid introducing of new methods, Economic problems. The protection of the Tribal art by the government and people help for protecting the Indian culture also. So by different way can introduce different tribal art indiverse regions of India.There is a major difference between commercial values and spiritual values of art but many artists believed that there is no different. In the end today commercial value of art has taken its spiritual value.

Recommendation: There is different suggestion for sustain of tribal art as introducing the tribal art by social media. Teaching tribal art in the Indian art universities help for increasing knowledge of youth about the Indian art and culture. With increasing the knowledge of people about tribal arts and their values the demand for tribal art also will be increase and it help to improving the economic condition of tribal artist. The successful protection from all people help for sustain of tribal art that presented the culture and identity of each tribe. The protection of the tribal art by the government and people help for protecting the Indian culture also. So by different way can introduce tribal artsin diverse regions of India. With support of tribal economics in another fields the tribal attempt topreservation traditional artand this matter helps to preserve theircultural identity. 


\section{References}

Chandy, K. T. (2004). House holds Economy in Tribal India .published by Uppal Publishing House. Enaksni, B. (1974). Folk and Tribal Designs of India, published by Russi. J. Taraporevala.

Harsha, V. D. (2000). The Advaita of Art, Published by Kapila Vatsyayan.

Jyotinda, J. (1984). Painted Myths of Creation: Art and Ritual of an Indian Tribe, publisher.

Kusipt, D. (2007). Art Values or Money values.

Sukeshdey, D. (2012). Essay on the general characteristics of Tribal Economy in India. 